\title{
PENINGKATAN IBADAH DAN AMALIAH SOSIAL BERBASIS MASJID
}

\author{
Husain Latuconsina ${ }^{1}$, Nova Septi Nazilatul Ula ${ }^{2}$, Saraskia Mei Choirunnisa ${ }^{2}$, Fanny \\ Maulida Kurniawati ${ }^{2}$, Rosi Nuresa ${ }^{2}$, Ahmad Syaifudin Zuhri ${ }^{2}$, Shinta Indriani Umbu \\ $\mathrm{Nay}^{3}$, Syamsul Arifin", Rasul Hamidi Rumkel ${ }^{4}$, Ahmad Amirudin Masykuri ${ }^{4}$, Ahmad \\ Muzayid $^{5}$ \\ ${ }^{1}$ Fakultas Matematika dan Ilmu Pengetahuan Alam, Universitas Islam Malang \\ 2 Fakultas Agama Islam, Universitas Islam Malang \\ ${ }^{3}$ Fakultas Keguruan dan Ilmu Pendidikan, Universitas Islam Malang \\ ${ }^{4}$ Fakultas Ekonomi dan Bisnis, Universitas Islam Malang \\ ${ }^{5}$ Fakultas Teknik, Universitas Islam Malang
}

Korespondensi email: husainlatuconsina@ymail.com

\begin{abstract}
ABSTRAK
Permasalahan yang dihadapi oleh generasi muda khususnya di desa Mulyoasri Kecamatan Amplegading-Kabupaten Malang adalah ketidakseimbangan antara hamblum minannas dan hablum minallah. Untuk mengatasinya, maka mahasiswa KKN-PPM Tematik berbasis Masjid yang tergabung dalam kelompok 24 Universitas Islam Malang merancang dan mengimplementasikan program kerja yang didasarkan pada hasil survei dengan metode purposive sampling. Kegiatan Pemberdayaan Masyarakat dengan tema "Peningkatan Ibadah dan Amaliah Sosial Berbasis Masjid", diharapkan dapat menjadi stimulan bagi generasi muda khsusnya dan masyarakat Desa Mulyoasri pada umumnya untuk membentuk karkter Islami berlandaskan Ahlu Sunnah Waljam'ah. Penanaman karakter Islami bagi generasi muda merupakan faktor yang penting untuk mewujudkan insan kamil yang dapat menyeimbangkan hablum minannas (hubungan antar sesama manusia) dan hablum minallah (hubungan antar manusai dengan sang pencipta Allah SWT). Untuk dapat mewujudkan kedua hal ini maka diperlukan penanaman nilai-nilai Islam sejak dini, dan peningkatan iman dan ketakwaan melalui pelaksaanaan ibadah sholat 5 waktu, membaca Al-Qur'an, jumat sedekah dan menjalankan amalan-amalan Islam Ahlusunnah Wal'jamaah yang telah menjadi tradisi masyarakat Nahliyin. Outcome yang diharapkan dari kegiatan ini adalah terwujudnya masyarakat yang berwatak Islam Aswaja untuk menggapi insan kamil.
\end{abstract}

Kata Kunci: pelatihan sholat; jumat sedekah; desa mulyoasri.

\section{PENDAHULUAN}

Masyarakat Desa Mulyoasri, Kecamatan Ampelgading Kabupaten Malang merupakan masyarakat agamis yang semuanya beragama Islam berhaluan Ahlu Sunnah Wal Jam'ah dengaan menjalankan amalan-amalan sebagai penciri tradisi ke-NU-an yang cukup kuat. Salah satu pedukuhan di Desa Mulyoasri adalah Pedukuhan Mulyoasri yang dulunya dikenal dengan sebutan Brandong menjadi pusat kegiatan pemberdayaan mahasiswa KKN-PPM Tematik.

Pedukuhan Mulyoasri memiliki tiga bangunan Masjid sebagai manivestasi kehidupan masyarakat yang agamis karena lekat dengan aktivitas keagamaan, dengan tradisi ke-NU-an yang selalu menjadikan Masjid sebagai pusat kegiatan keagamaan. 
Berdasarkan survei yang dilakukan oleh mahasiswa KKN-PPM tematik berbasis Masjid yang tergabung dalam kelompok 24 Universitas Islam Malang, ditemukan salah satu persoalan yang ada pada pedukuhan Mulyoasri adalah anak-anak sekolah banyak yang belum mengetahui tata cara sholat lima waktu yang baik dan benar dan mulai memudarnya nila-nilai sosial antar angota masyarakat.

Berdasarkan permasalahan yang ditemukan, maka mahasisswa KKN-PPM Tematik berbasis Masjid merencanakan program kerja yang dijalankan selama 1 bulan penuh dengan 2 program unggulannya, meliputi: 1) pelatihan tata cara sholat 5 waktu bagi anak usia dini yang didukung dengan program tambahan yaitu pendampingan belajar membaca Al-Qur'an yang baik dan benar, 2) Jumat Sedekah, dengan membagikan takjil setiap selesai sholat jumat, dan didukung program tambahan yaitu penyuluhan dengan tema "Pemberdayaan dan Kemakmuran Masjid", Juma'at bersih Masjid, Khotmil Qur'an ba'da subuh, Tahlilan, Asyrokalan, dan Diba'an.

Pentingnya pelatihan sholat bagi anak usia dini dan Sedekah untuk dapat mewujudkan insan kamil yang dapat meningkatkan hubungannya dengan Allah SWT (hablum minallah) sekaligus mempererat tali silaturahmi antar sesama (hambul minannas) (Astuti \& Aziz, 2019) (Aristanto et al., 2020). Menurut (Yurwanto, 2014), bahwa sasaran pertama Islam adalah perbaikan individu-individu agar masing-masing menjadi khalifah (wakil Allah), pencipta kedamaian, dan kebersamaan. Untuk menjadi insan kamil, manusia diberi jalan bukan hanya iman dan takwa, melainkan juga amal saleh.

Terkait belajar membaca Al-Qur'an, menurut Ulfa \& Arifi (2017), dunia pendidikan mendapatkan peran yang penting dalam pembentukan dan pengembangan potensipotensi anak. Salah satu pendidikan yang penting dalam pembangunan anak-anak ialah pendidikan al-Qur'an. Membangun pendidikan Al-Qur'an kepada anak-anak mampu menanamkan ruh Islam dalam diri mereka (Siregar, 2016).

Rasulullah SAW adalah tipikal insan kamil, manusia dengan tingkat ketakwaan dan kesalehan sosial paling tinggi (Martino et al., 2018). Menurut Yurwanto (2014), secara garis besar kesalehan sosial Rasulullah dapat dirumuskan dalam tiga kata kunci: Salam, Kalam dan Tha'am. Salam adalah berempati kepada orang lain. Kalam artinya berbicara, misalnya jika manusia dalam kondisi tidak dapat memberikan bantuan materi, penolakan harus dilakukan dengan sikap yang halus dan ucapan yang baik, sedangkan Tha'am secara bahasa artinya makan adalah pendekatan pribadi, maksudnya memberi makan kepada orang kelaparan dan menyantuni mereka yang membutuhkan.

Kehidupan di era revolusi industri 4.0 dengan kemajuan teknologi informasi yang berkembang pesat, namun memberikan dampak pada kemerosotan moral sebagai dampak dari masuknya budaya baru (budaya asing) yang tidak terbendung dan tidak sejalan dengan nilai-nilai ajaran Islam (Rahman, 2016). Untuk dapat menyelamatkan generasi milenial dari inflitrasi budaya barat yang umumnya memberikan dampak negatif, maka generasi muda juga perlu ditanamkan budaya membaca Al-Qur'an, karen Al-Qur'an merupakan kitab suci yang mampu memberikan ketenangan jiwa.

Menurut Shihab (1996), bahwa Al-Qur'an bukan hanya sekedar tuntunan tentang pelaksanaan ibadah yang bersifat ritual belaka, namun lebih dari itu Al-Qur'an merupakan pedoman bagi penyelesaian berbagai problematika hidup, sehingga jika dihayati dan dimalkan secara istiqamah, maka Al-Qur'an akan menjadikan pikiran, rasa, dan karsa kita mengarah kepada realitas keimanan yang dibutuhkan bagi stabilitas dan ketentraman hidup pribadi dan masyarakat (Baiti \& Razzaq, 2017). 


\section{METODE}

\section{Lokasi dan Partisipan}

Pelaksanaan Pemberdayaan masyarakat melalui kegiatan Kuliah Kerja Nyata Pembelajaran Pemberdayaan Masyarakat Tematik (KKN-PPM Tematik) berbasis Masjid yang dilaksanakan selama 1 bulan, dimulai sejak 1 Februari sampai dengan 1 Maret 2020, yang bertempat di tiga Masjid yang ada pada Dusun Mulyoasti, Desa Mulyoasri, Kecamatan Amplegading, Kabupaten Malang - Jawa Timur (Gambar 1). Adapun masyarakat sasaran yang menjadi objek sekaligus subjek kegiatan pemberdayaan anakanak sekolah Dasar dan masyarakat umum lainnya.

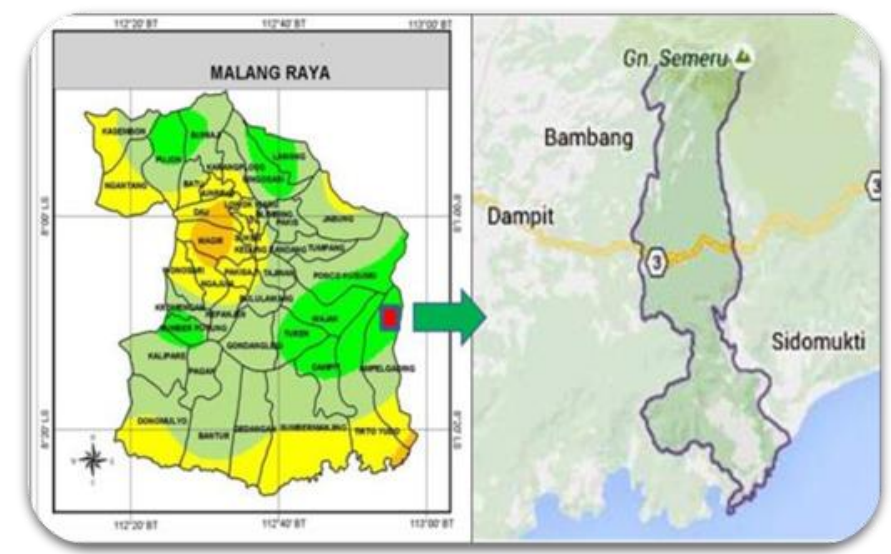

Gambar 1. Peta Lokasi Kegiatan KKN-PPM Tematik berbasis masjid di Desa Mulyoasri, Kecamatan Amplegading, Kabupaten Malang - Jawa Timur.

Program pelatihan sholat 5 waktu pada 3 masjid yakni Masjid Baittur Rohim bertempat di RT 25, Masjid Muttaqin bertempat di RT 27, dan Masjid Darul Hidayah bertempat di RT 30. Pelatihan sholat 5 waktu ini dilaksanakan pada pukul 15.00 untuk Masjid Darul Hidayah, dan pada pukul 18.00 untuk masjid Muttaqin dan Baittur Rohim.

\section{Alat Bantu}

Dalam melaksanakan program pemberdayaan berbasis Msjid, kelompok 24 menggunaka beberapa alat bantu seperti Laptop, Projekor dan Buku Panduan Sholat.

\section{Tahapan Kegiatan dan Metode Pemberdayaan}

Kegiatan pemberdayaan masyarakat berbasis Masjid yang dilaksanakan oleh Mahasiswa peserta KKN-PPM Tematik Kelompok 24 Universitas Islam Malang dengan tema "Peningkatan Ibadah dan Amaliah Sosial berbasis Masjid" dilakukan melalui beberapa tahapan: 1) Survei lokasi, 2) konsultasi publik sekaligus silaturahmi dengan masyarakat (kepala desa dan perangkat desa, kepala dusun, dan tokoh masyarakat maupun tokoh Agama) (Gambar 2), 3) penyusunan program kerja pemberdayaan, 4) sosialisasi 5) pelatihan/pendampingan, dan 6) Evaluasi. 


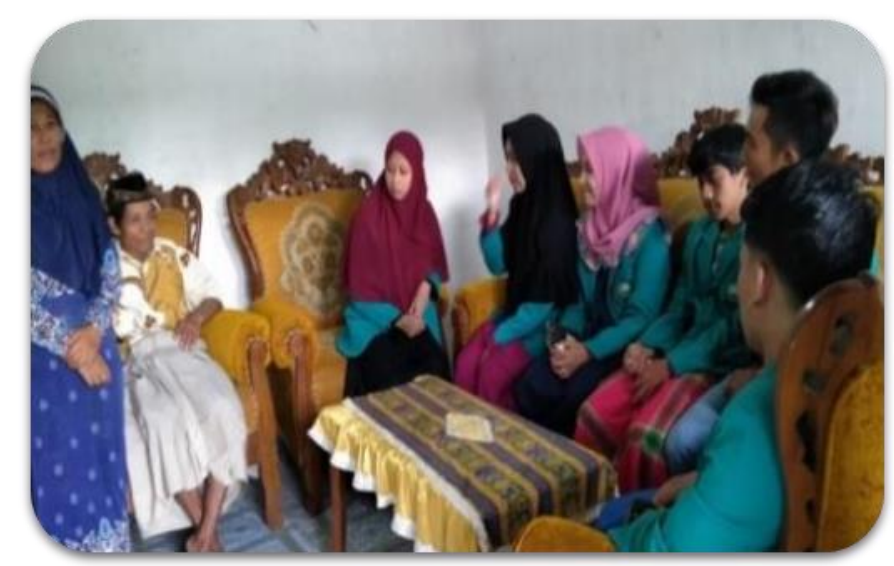

Gambar 2. Silaturahmi dan konsultasi publik untuk menyerap aspirasi masyarakat

Pada tahapan identifikasi permasalahan di lapangan menggunakan metode Survai (Morrisan, 2012) dan penentuan responden secara purposive, yaitu dengan menentukan responden berdasarkan pertimbangan tetentu yang dinilai dapat memenuhi tujuan survei (Morrisan, 2012) (Nizar, 2011).

\section{HASIL DAN PEMBAHASAN}

\section{Program Unggulkan KKN-PPM Tematik Kelompok 24 Berbasis Masjid}

Karakteristik masjid yang baik dengan tujuan dapat membentuk dan terciptanya suasana yang menyenangkan, mendamaikan, serta memberikan rasa aman terhadap lingkungan Masjid. Selain sebagai tempat ibadah, masjid juga bisa digunakan sebagai sarana keagamaan lainnya seperti belajar, mengaji, kajian dan lain sebagainya. Dalam hal lain masjid juga dapat difungsikan sebagai bangunan yang dapat mengandung makna tunduk dan patuh kepada Allah, hal inilah menjadi salah satu hakikat masjid. Seperti yang dijelaskan didalam Al-Qur'an surat Al-Jin ayat 18 yang artinya: "Dan sesungguhnya masjid-masjid itu adalah kepunyaan Allah. Maka janganlah kamu menyembah seseorangpun di dalamnya di samping (menyembah) Allah".

Kelompok 24 berbasis Masjid ini memilih program unggulan pelatihan sholat 5 waktu karena dirasa anak-anak usia dini di Desa Mulyoasri ini masih kurang memiliki tanggung jawab untuk menjalankan ibadah. Mereka masih menganggap bahwa sholat bukanlah suatu kewajiban terpenting dalam hidup, sehingga ia tidak akan mengerti fungsi dan hakikat sholat. Ketika melakukan sholat 5 waktu mereka di Desa Mulyoasri masih banyak yang bergurau, menoleh kekanan ke kiri.

Menurut Hermawan (2018), salah satu kegiatan yang dapat dilakukan untuk melatih anak sholat adalah melalui pembiasaan pada anak. Membiasakan anak untuk sholat lima waktu dan sholat sunah yang lain, yang dilakukan kepada anak secara terus-menerus secara tidak langsung akan menanamkan kebiasaan. Ketika anak tidak melaksanakan kebiasaannya, maka akan timbul rasa kekurangan bahkan kehilangan kegiatan yang biasanya anak lakukan. Dengan demikian, sholat akan menjadi kebiasaan yang dilakukan anak secara terus-menerus.

Oleh karena itu, kelompok 24 ini membuat program unggulan praktek sholat kepada anak-anak usia dini agar mampu menjadikan mereka memiliki rasa kecintaan terlebih dahulu terhadap beribadah kemudian nantinya akan terbentuk rasa keinginan untuk mempelajari lebih mendalam dan diharapkan menjadi kebiasaan untuk dijalankan terus menerus.

Selain program unggulan sholat 5 waktu kelompok 24 berbasis masjid juga memiliki satu lagi program yang dinamakan Jumat Sedekah, jumat sedekah ini 
menyangkut seluruh elemen warga yang ada di Desa Mulyoasri yang dilaksanakan setiap selesai sholat jumat yang bertujuan memberikan penanaman terhadap warga di Desa Mulyoasri untuk berbagi terhadap sesama. Dengan demikian maka dapat mewujudkan insan kamil, dimana upaya membangun karakter kesalehan sosial menurut Yurwanto (2014) adalah untuk mewujudkan keharmonisan hubungan secara vertikal dengan Sang Pencipta (hablum minallah), juga hubungan harmonis dengan manusia (hablum minannas). Jika kedua aspek sudah terpenuhi maka akan menjadi nyatalah perwujudan seorang insan kamil atau manusia sempurna.

\section{Program Unggulan "Pelatihan Sholat lima waktu bagi Anak Usia Dini”}

Program pelatihan sholat 5 waktu (Gambar 3) diselenggarakan oleh mahasiswa KKN-PPM Tematik berbasis Masjid pada 3 masjid yakni Masjid Baittur Rohim bertempat di RT 25, Masjid Muttaqin bertempat di RT 27, dan Masjid Darul Hidayah bertempat di RT 30. Pelatihan sholat 5 waktu ini dilaksanakan pada pukul 15.00 untuk Masjid Darul Hidayah, dan pada pukul 18.00 untuk masjid Muttaqin dan Baittur Rohim.

Untuk menjalankan progtam pelatihan sholat lima waktu bagi anak, mahasiswa KKN juga memperhatikan tahapan umur mulai dari umur 3-5 tahun dengan pemberian tantangan, kemudian pada umur 0-12 tahun dengan pemberian pembelajaran yang baik, yang menyenangkan dan memberi kesan yang baik karena pada masa ini adalah masa emas. Hal ini mampu mempercepat proses program yang dijalankan dikelompok 24.

Menurut Hermawan (2018), usia dini merupakan usia emas atau the golden age. Pada fase ini anak dapat menyerap semua pengetahuan yang didapat pada lingkungan sekitar dengan maksimal. Pada usia ini penanaman nilai-nilai keagamaan haruslah dilakukan secara terus-menerus, sehingga akan menjadi kebiasaan anak.
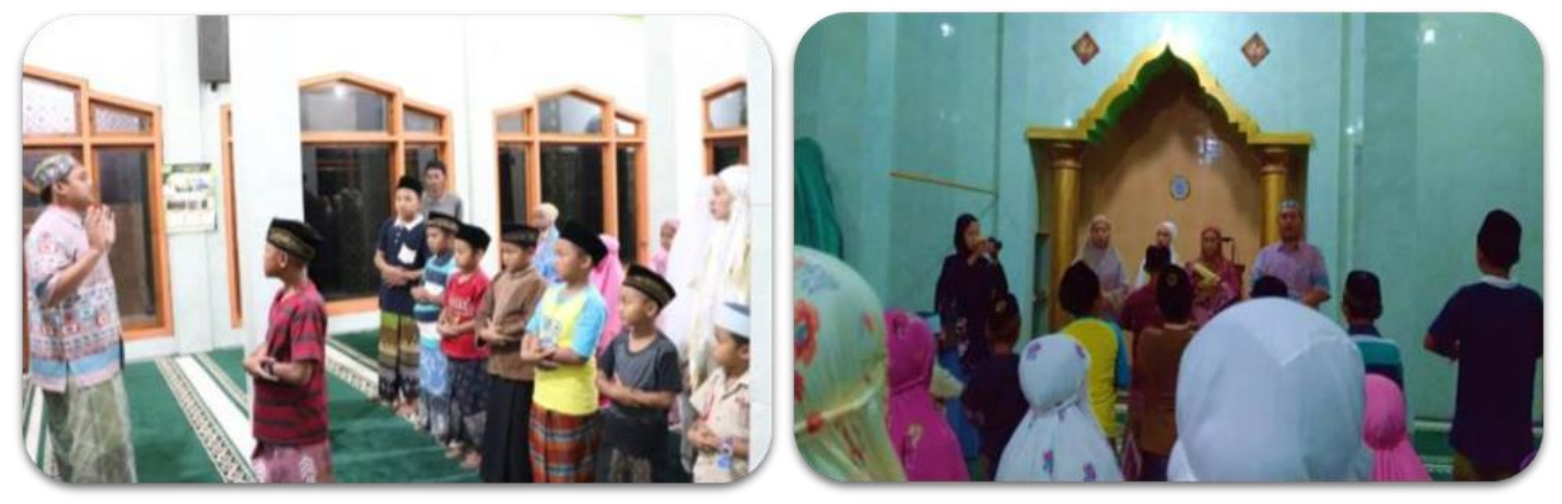

Gambar 3. Pelatihan tata cara sholat lima waktu yang baik dan benar kepada anak-anak

Menurut Hermawan (2018), pada fase usia emas sangat cocok untuk orangtua atau pendidik mengoptimalkan seluruh potensi anak, di mana potensi ini dapat berkembang apabila seluruh kegiatan anak mendapatkan arahan dan bimbingan dari orangtua atau pun guru. Adapun cara mendidik dan mengarahkan anak bisa dilakukan bisa melalui pemberian keteladanan, pembiasaan, maupun pengajaran secara langsung.

Pelatihan sholat lima waktu mejadi pogram unggulan mahasisswa KKN-PPM Kelompok 24 ini penting untuk dilakukan dengan harapan anak-anak usia dini akan terbiasa dan dapat menjalankan perintah sholat 5 waktu yang menjadi salah satu rukun Islam sebagaimana perintah sholat pada anak berdasarkan Hadis Nabi SAW; 
"Perintahkanlah anak-anak kalian yang sudah berumur tujuh tahun. Dan pukulah mereka karena meninggalkannya ketika telah berumur 10 tahun. Serta pisahkanlah mereka dalam tempat tidur mereka. (Hadis hasan. Diriwayatkan oleh Abu Dawud dengan sanad yang Hasan). Selanjuynta dari Abu Tsurayyah Sabrah bin Ma'bad Al Jauhani, ia berkata, Rasulullah SAW Bersabda: "Ajarilah anak-anak sholat ketika sudah berumur tujuh tahun dan pukullah mereka karena meninggalkan sholat jika mereka sudah berumur sepuluh tahun" (hadis hasan yang diriwayatkan Abu Dawud dan at-Tirmidzi).

\section{Program Unggulan “Jum'at Bersedekah"}

Mahasiswa KKN-PPM Tematik berbasis Masjid memiliki program unggulan ke-2 yaitu menggiatkan sedekah di hari jum'at. Kegiatan ini dimaksudkan untuk mengajak masyarakat yang berkempuan lebih agar tergerak hatinya untuk bersedekah di hari jum'at yang merupakan hari yang sangat diajurkan karena merupakan hari sucinya umat Islam.

Sedekah merupakan salah satu amal ibadah yang besar pahalanya, keberadaannya bukan hanya berkaitan dengan penghambaan kepada Sang Khaliq, namun juga merupakan sikap solidaritas kepada sesama manusia (Hamrin, 2018). Allah memuji orang yang bersedekah tidak hanya dalam satu ayat, namun di beberapa ayat di Al-Qur'an diantaranya (QS. Al-Baqarah ayat 3) Artinya: "(yaitu) mereka yang beriman kepada yang ghaib, yang mendirikan shalat, dan menafkahkan sebagian rizki yang Kami anugerahkan kepada mereka." Selain Ayat Al-Qur'an yang menganjurkan pentingnya shodakoh, juga dalam beberapa hadits Rasulullah menyampaikan beberapa keutamaan bersedekah. Di antaranya: Tidaklah seorang hamba memperbaiki sedekahnya kecuali Allah memperbaiki pengganti atas harta tinggalannya." (HR. Ibnu al-Mubarak).

Sedekah di hari jum'at yan berbasis masjid ini dilakukan sebagai salah satu bentuk pemebrdayaan masyarakat, dengan harapan agar masyarakat dusun Mulyoasri, Desa Mulyoasri dapat meningkatkan solidaritas sosial melalui sedekah di hari jumat (Gambar 4). Kegiatan sedekah hari jum'at ini dilakukan selama 3 jum'at berturut-turut selama kegiatan KKN-PPM berlangsung, yang dilakukan pada 3 masjid yang ada pada pedukuhan Mulyoasri.
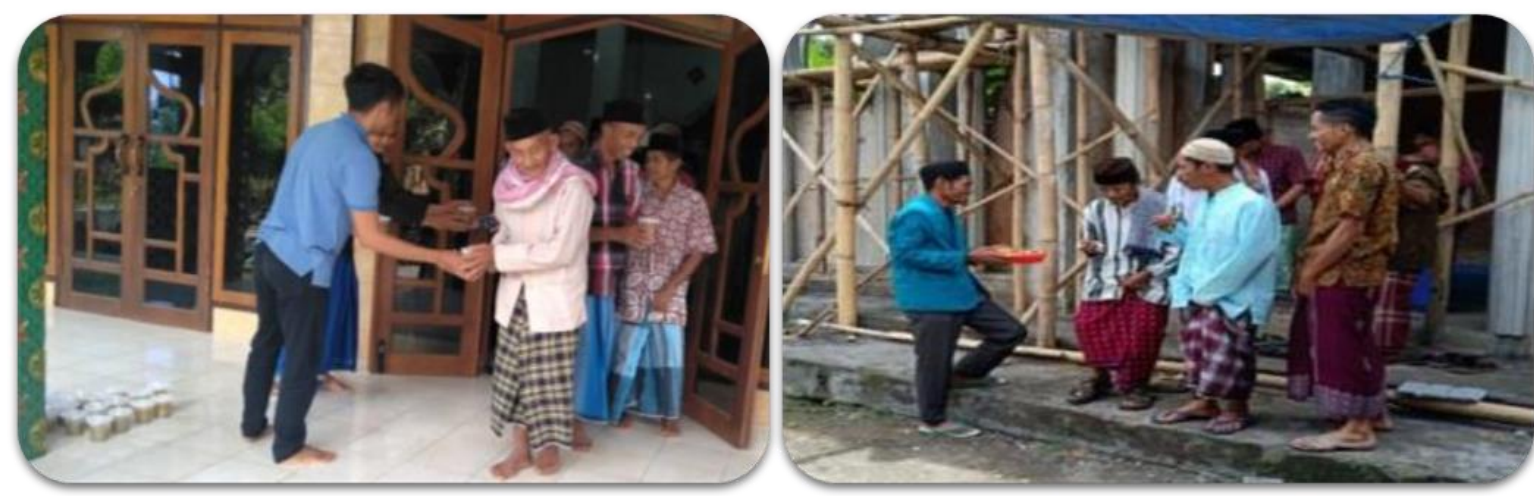

Gambar 4. Kegiatan Jum'at Bersedekah berbasis Masjid oleh mahasiswa KKN-PPM Tematik

Kegiatan 'Sedekah Jum'at” yang dilakukan oleh masyarakat ini pada prinsipnya memiliki dua tujuan, yaitu: 1) menjalin silaturahmi dengan msyarakat setempat, 2) mengajak masyarakat setempat untuk bersedekah sebagai bentuk amaliah sosial.

Menurut Hamrin (2018), bahwa sedekah bisa dilakukan kapan saja dan di mana pun berada serta kepada siapapun. Namun bersedekah memiliki pahala lebih besar 
bila dilakukan di waktu-waktu utama, di antaranya di hari Jumat. Selanjutnya di dalam beberapa hadits, disebutkan anjuran khusus untuk bersedekah di hari Jumat. Di antaranya hadits "Dari Jabir bin Abdillah berkata, Rasulullah bersabda saat beliau berada di atas mimbarnya, wahai manusia bertobatlah kalian kepada Tuhan kalian sebelum kalian mati. Bersegeralah kembali kepada-Nya dengan amal-amal saleh, sambunglah hubungan antara Tuhan dan kalian dengan memperbanyak dzikir dan sedekah di saat sunyi dan ramai, maka kalian diganjar, ditolong dan diberi rizki." (HR. al-Kassi dalam kitab al-Muntakhab min Musnad Abd bin Humaid).

Di dalam literatur fiqih, anjuran bersedekah di hari Jumat sebagaimana waktuwaktu utama yang lain memiliki nilai keutamaan lebih besar dari pada waktu lainnya. Hari Jumat termasuk waktu yang utama untuk bersedekah, karena Jumat merupakan hari raya orang Islam sebagaimana disebutkan dalam hadits.

Penekanan bersedekah di hari Jumat dan waktu-waktu utama yang lain bukan berarti dianjurkan untuk menunda sedekah di waktu-waktu tersebut. Namun yang dimaksud adalah bersedekah di waktu-waktu tersebut memiliki pahala yang lebih besar dibandingkan waktu-waktu lainnya. Seseorang dianjurkan bersedekah kapan saja dan lebih utama lagi dilakukan di hari-hari spesial seperti Jumat (Rusdi et al., 2018).

\section{Program Tambahan Berbasis Masjid}

Selain melaksanakan program Unggulan berbasis Masjid, mahasiswa KKN-PPM Tematik kelompok 24 juga melaksanakan program tambahan seperti kegiatan Mengajar cara membaca Al-Qur'an, Penyuluhan pemberdayaan dan kemakmuran Masjid, Pembersihan Masjid, Khotmil Qur'an, Tahlilan, Asyrokalan, dan Diba'an.

Mengajar membaca Al-Qur'an (Gambar 5) dijalankan sebagai program pendukung, untuk memperkuat program unggulan terutama pelatihan sholat lima watu. Dengan pendidikan al-Qur'an sejak dini, fitrah suci anak niscaya dapat dilestarikan dengan baik. Sedangkan menurut Astuti \& Aziz (2019), kehanifan anak di sektor keberagamannya akan eksis dengan kitab suci, sehingga jika konsep pendidikan Al-Qur'an ditanamkan sejak kecil, maka dapat dijadikan sebagai tonggak utama terbentuknya mental dan kepribadian anak sehat untuk menstimulasi pengembangan potensi anak.

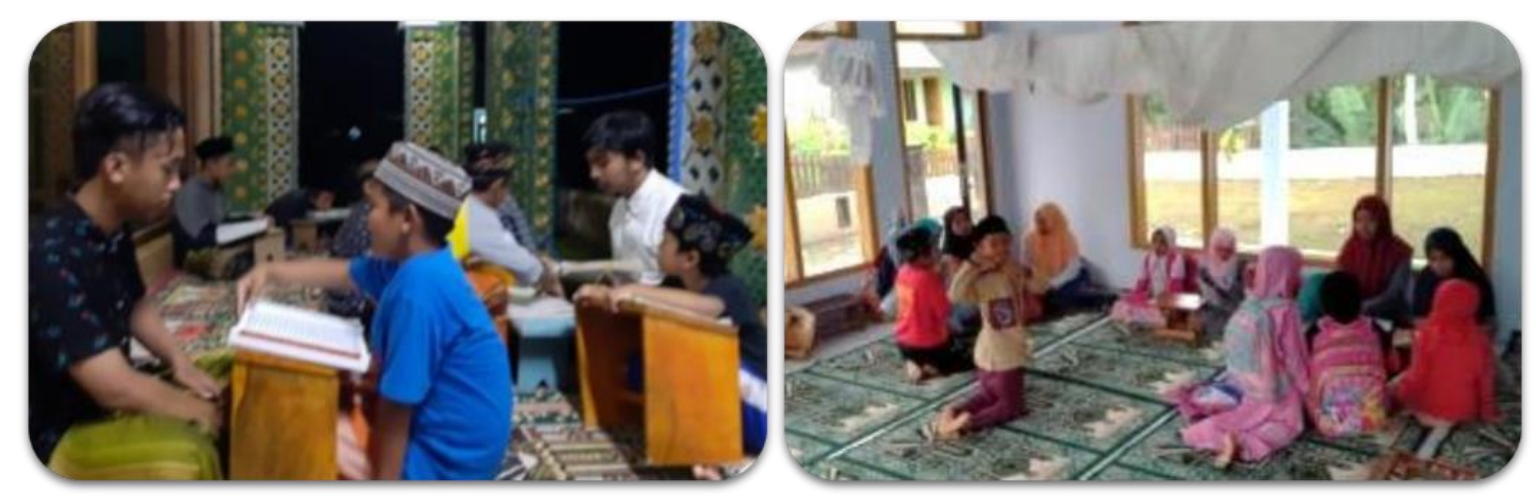

Gambar 5. Belajar Mengaji bagi Anak-anak usia dini berbasis Masjid

Pembelajaran membaca Al-Qur'an bagi anak-anak usia dini sangat diperlukan pendamping, sebagaimana menurut Ulfa \& Arifi (2017), bahwa bimbingan seorang qori' dalam proses menghafal berbagai surat pendek, menjadikan peserta didik mampu mencapai tahsin yaitu cara memperbaiki hafalan dan memperbagus suara dalam menghafal Al-Qur'an dengan tartil yang memperhatikan tajwidnya. 
Kegiatan pendukung program unggulan lainnya adalah "Khotmil Qur'an” selama sebulan yang berlangsung di Masjid setelah sholat subuh (Gambar 6). Ini merupakan program yang disinergikan dengan kegiatan rutin masyarakat desa. Kegiatan ini bertujuan selain sarana silaturahmi dengan masyarakat, juga menjadi strategi pemberdayaan untuk mengajak masyarakat secara bersama-sama melaksanakan khotmil Qur'an.

Banyak keutamaan membaca ayat Al-Qur'an, menurut Rasikh (2019), membaca Al-Qur'an termasuk ibadah paling utama di antara ibadah-ibadah yang lain, sebagaimana yang diriwayatkan oleh an-Nu'man ibn Basyir: Rasulullah shallahu 'alaihi wasallam bersabda, "Sebaik-baiknya ibadah umatku adalah membaca Al-Qur'an." (HR. al-Baihaqi).

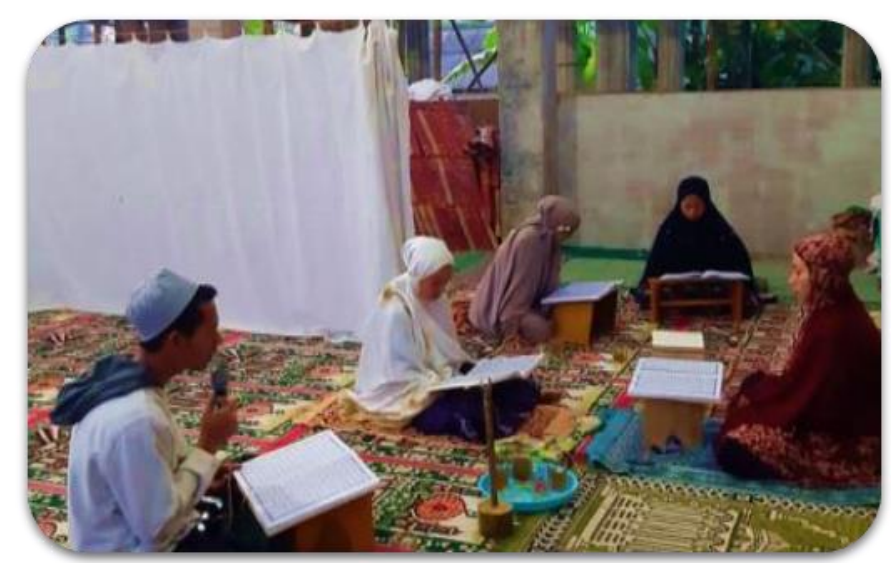

Gambar 6. Kegiatan Khotmil Qur'an Setiap selesai Shloat subuh bersama masyarakat

Menurut Rasikh (2019), bahwa hadits tentang keutamaan membaca Al-Qur'an yang cukup familiar adalah hadits riwayat Abdullah Ibnu Mas'ud; Rasulullah shallallahu 'alaihi wasallam bersabda, "Siapa saja membaca satu huruf dari Kitabullah (Al-Qur'an), maka dia akan mendapat satu kebaikan. Sedangkan satu kebaikan dilipatkan kepada sepuluh semisalnya. Aku tidak mengatakan alif lâm mîm satu huruf. Akan tetapi, alif satu huruf, lâm satu huruf, dan mîm satu huruf," (HR. At-Tirmidzi).

Untuk mendukung kegiatan pemberdayaan berbasis Masjid, maka kebersihan lingkungan masjid menjadi salah satu faktor penting. Berdasarkan ha ini, maka salah satu program tambahan lainnya yang dijalankan oleh mahasiswa KKN-PPM Tematik Universitas Islam Malang yang berbasis Masjid dari Kelompok 24 adalah untuk mendukung program unggulan adalah "bersih Masjid" setiap jum'at pagi (Gambar 7).

Program ini dijalankan sebagai bagian integral dari upaya pemberdayaan masyarakat dengan memberikan contoh bagi generasi muda pada desa Mulyoasri untuk memelihara Masjid sebagai manivestasi upaya memakmurkan Masjid, sebagaiana sabda Rasulullah Muhammad SAW bahwa "Barang siapa yang mengeluarkan kotoran dari masjid maka Allah akan membangunkan untuknya sebuah rumah di surga," (HR Ibnu Majah). 


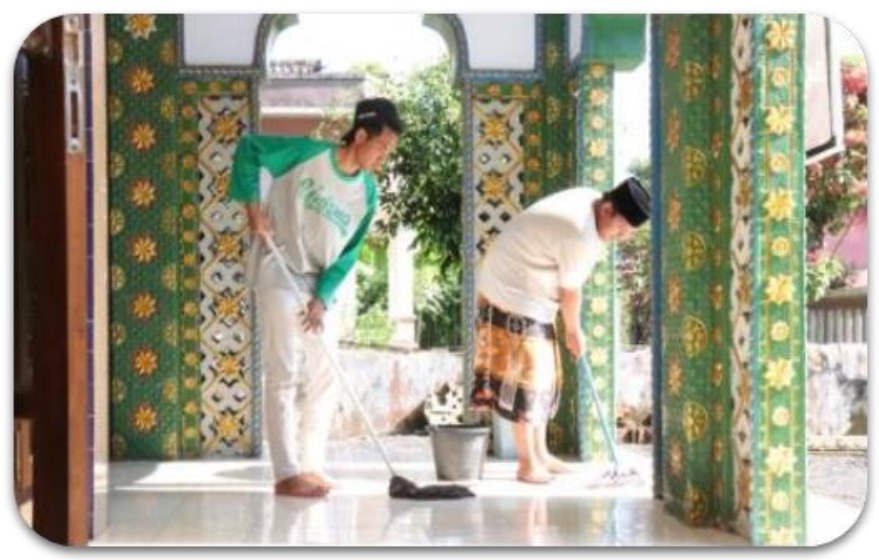

Gambar 7. Pembersihan Masjid setiap jum'at pagi bersama masyarakat

Untuk memperkuat program unggulan berbasis Masjid, maka dilaksanakan program tambahan yaitu kajian Islam Aswaja sebagai salah satu langkah untuk lebih memakmurkan Masjid, kegiatan ini bertujuan untuk memperkuat dan memberi pengetahuan yang baru untuk masyarakat yang ada di Desa Mulyoasri agar mampu mengembangkan masjid sebagai pusat peradaban masyarakat. Adapun yang menjadi narasumber pada kegiatan penyuluhan adalah Kukuh Santoso yang merupakan dosen Fakultas Agama Islam sekaligus Takmir Masjid Ainul Yaqin Universitas Islam Malang (Gambar 8).
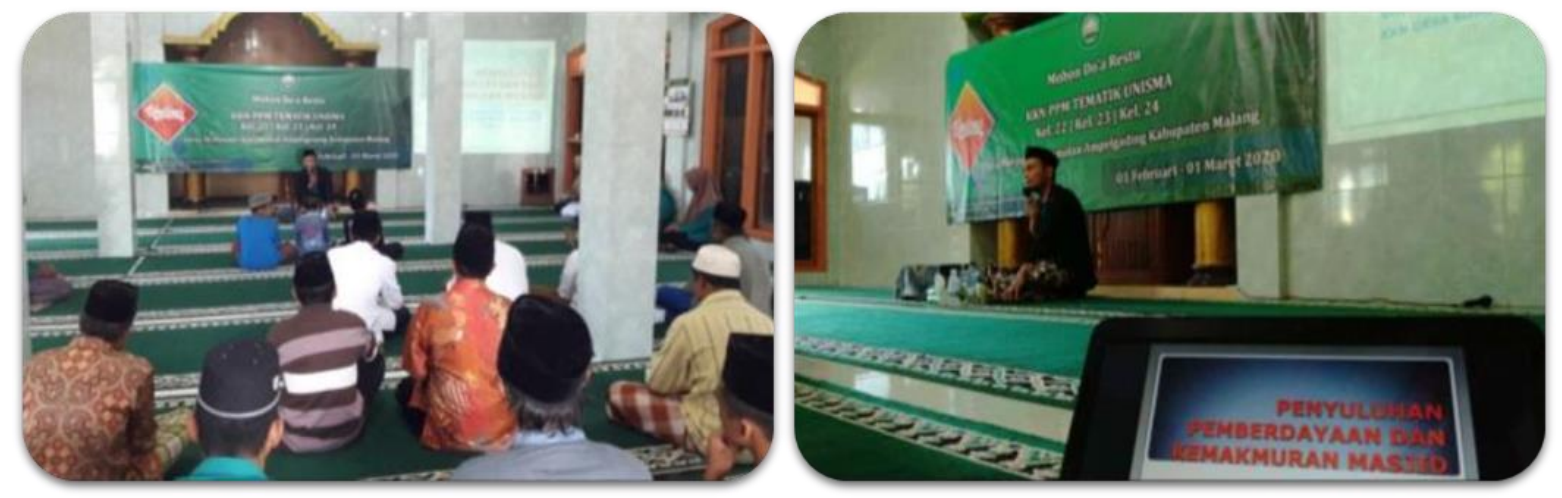

Gambar 8. Kegiatan Pendukung untuk peningkatan kemakmuran Masjid

Tema penyuluhan adalah "Pemberdayaan dan Kemakmuran Masjid", Kukuh Santoso menyampikan dalil terkait pentingnya memakmurkan Masjid sepeti yang tersurat dalam QS. At-Taubah 9:8, yang artinya: "Hanyalah yang memakmurkan masjid-masjid Allah ialah orang-orang yang beriman kepada Allah dan hari kemudian, serta tetap mendirikan shalat, menunaikan zakat dan tidak takut (kepada siapa pun) selain kepada Allah, maka merekalah orang-orang yang diharapkan termasuk golongan orang-orang yang mendapat petunjuk".

Menurut Kukuh Santoso, perwujudan cinta terhadap Masjid dapat diimplementasikan melalui upaya memakmurkannya, yang dalam tindakan nyata dapat berupa: 1). Selalau merasa rindu kepada Masjid, 2). Bersedia berkorban untuk Masjid, 3) rajin mendatangi Masjid, dan 4) menghormati Masjid. Selanjutnya menurut Kukuh Santoso, Masjid merupakan pusat pembinaan umat Islam, yang didalamnya dapat berfungsi sebagai ; 1) sebagai tempat ibadah, 2) sebagai tempat diskusi Agama dan bermusyawarah, 3) sebagai tempat belajar mengajar Al-Qur'an dan pendidikan Agama Islam, dan 4) sebagai sarana ibadah sosial. 
Menjadikan Masjid sebagai pusat pengembangan peradaban masyarakat ini memiliki berbagai manfaat, diantaranya adalah untuk dapat menangkal berbagai informasi yang berkembang di tengah masyarakat sebagai dampak dari perkembangan teknologi informasi di era Revolusi Industri 4.0. Menurut Latuconsina (2019), dampak buruk era revolusi Industri 4.0 melalui penyebaran berbagai informasi secara bebas dan tidak terkendali, dan menurunnya nalar kiritis masyarakat dan mahasiswa dalam menyeleksi beragam informasi yang masuk, sehingga tidak mampu membedakan informasi yang benar dan hoaks, dimana fenomena ini semakin berkembang akibat minimnya kemampuan literasi untuk dapay menganalisis dan mengkritisi semua informasi yang didapatkan, dengan mencari pembanding dari berbagai sumber untuk mendapatkan keyakinan dalam menilai kebenaran secara objektif, komprehensif dan mendalam. Fakta inilah sebagai variable penting masuknya ideologi radikalisme akan berkembang pesat di tengah masyarakat.

Tiga kegiatan masyarakat yang disinergikan dengan kegiatan pemberdayaan mahasiswa KKN-PPM Tematik berbasis Masjid adalah Tahlilan, Asyrokalan, Diba'an (Gambar 9). Keikutsertaan Mahasiswa KKN-PPM dalam rutinitas amaliah yang dijalankan ole masyarakat ini memiliki dua tujuan, yaitu: 1) media sosialisasi mahasiswa dengan masyarakat untuk meningkatkan hablum minannas, dan 2) media untuk turut serta meningkatkan partisipasi masyarakat dalam kegiatan dimaksud sebagai manivestasi peningkatan silaturahmi antar warga masyarakat dan upaya mempertahankan tradisi kaum Nahdliyin yang sudah dicontohkan oleh para ulama terdahulu. Upaya ini dilaksakanan dalam ranga membentengi masyarakat di tengah masuknya faham-faham yang membawa ide pemurnian Islam (kembali ke Al-Qur'an dan hadist), dan sangat masif tersebar di Indonesia. Umumnya kelompok-kelompok Islam ekstrim ini selalu menganggap amaliah-amalaiah kaum Nahdliyin ini bid'ah dan tidak memiliki dalil.
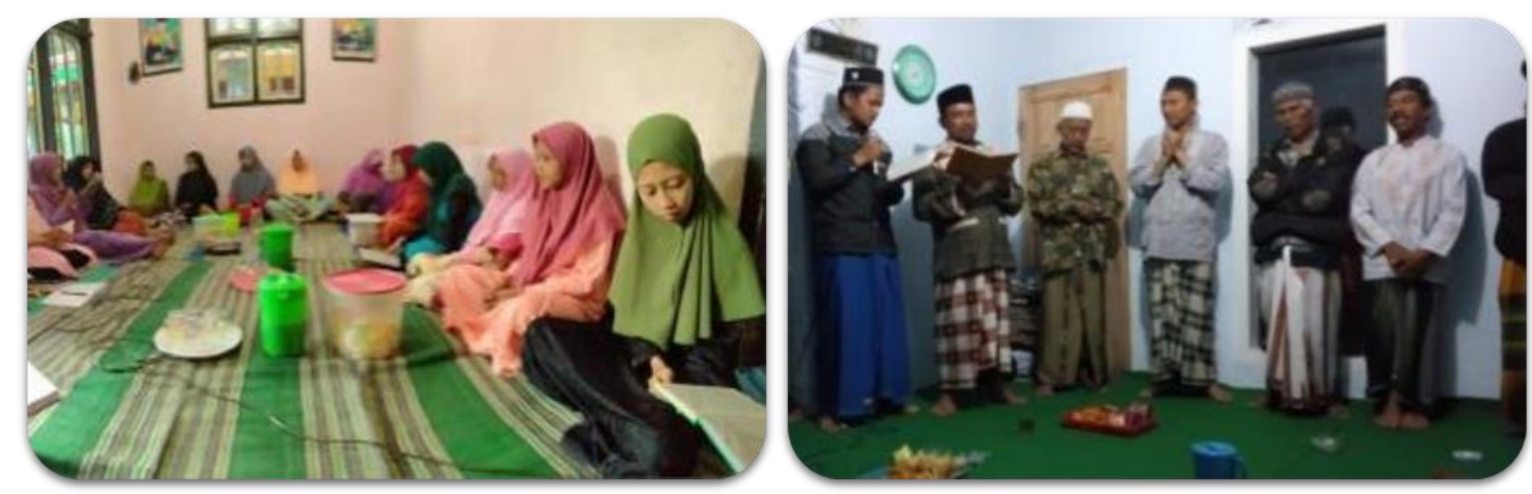

Gambar 9. Berbagai kegiatan pendukung mahasiswa KKN-PPM Tematuk berbasis Masjid yang disinergikan dengan kegiatan rutin masyarakat

Adapun keikutsertaan mahasiswa peserta KKN-PPM Tematik dalam berbagai kegiatan rutin masyarakat yang terkait amalan Islam Aswaja adalah untuk memenuhi beberapa tujuan, yaitu: 1. Upaya sosialisasi dan berbaur dengan masyarakat desa setempat, 2. Menjadi contoh bagi generasi anak-anak yang merupakan generasi muda pada desa setempat untuk ikut melestarikan amalan-amalan yang dilajankan oleh kaum Nahdliyin sebagai bentuk implementasi Ajaran Islam Ahlusunnah Waljma'ah. Tujuan ke-2 ini sangat penting untuk dapat mmebendung pemahaman-pemahaman golongan islam puritan yang sangat bertolak belakang dengan nilai-nilai Islam Aswaja yang selama ini diamalkan oleh sebagian besar masyarakat di Indonesia yang berafiliasi dengan Nahdlatul Ulama baik secara struktural maupun kultural. 


\section{Tahapan-Tahapan Kegiatan}

Kegiatan Pelaksanaan Kuliah Kerja Nyata - Pembelajaran Pemberdayaan Masyarakat berbasis Masjid yang dijalakan oleh kelompok 24 Mahasiswa Universitas Islam Malang, dengan tahapan-tahapan kegiatan sebagaimana Tabel 1.

Tabel 1. Tahapan Pelaksanaan KKN-PPM Tematik dengan tema "Peningkatan Ibadah dan Amaliah Sosial berbasis Masjid

\begin{tabular}{|c|c|c|c|}
\hline No. & Tahapan-tahapan & Uraian Kegiatan & Target Pencapaian \\
\hline 1. & Minggu Pertama & $\begin{array}{l}\text { Survei lokasi, silaturahim dan } \\
\text { konsultasi publik, pembagian } \\
\text { tugas dan merancang program } \\
\text { unggulan. }\end{array}$ & $\begin{array}{l}\text { Tersusunya Rencana Program } \\
\text { kerja Unggulan berbasis Masjid }\end{array}$ \\
\hline 2. & Minggu Kedua & $\begin{array}{l}\text { Melakukan Pemetaan program, } \\
\text { penyuluhan dan melaksanakan } \\
\text { program Unggulan melalui } \\
\text { pelaksanaan program pelatihan } \\
\text { sholat, pelajar membaca Al- } \\
\text { Qur'an, Jum'at sedekah }\end{array}$ & $\begin{array}{l}\text { Terealisasinya program kerja } \\
\text { unggulan dalam bentuk } \\
\text { Sosialisasi, pendidikan / } \\
\text { pelatihan dan pembagian Takjil } \\
\text { sebagai bentuk Jum'at sedekah" }\end{array}$ \\
\hline 3. & Minggu Ketiga & $\begin{array}{l}\text { Melanjutkan program pendidikan } \\
\text { / pelatihan sholat dan pelajar } \\
\text { membaca Al-Qur'an, jum'at } \\
\text { sedekah dan peyuluhan } \\
\text { pentingnya memkamurkan } \\
\text { Masjid }\end{array}$ & $\begin{array}{l}\text { Terealisasinya kegiatan pelatihan } \\
\text { dan pedidikan sholat } 5 \text { waktu } \\
\text { dan belajar membaca Al-Qur'an, } \\
\text { jum'at sedekah, dan } \\
\text { terealiasisnya kegiatan } \\
\text { penyuluhan. }\end{array}$ \\
\hline 4. & Minggu Keempat & $\begin{array}{l}\text { Evaluasi Pelaksanaan Program } \\
\text { Kerja }\end{array}$ & $\begin{array}{l}\text { Terealisasinya seluruh tahapan } \\
\text { program kerja unggulan }\end{array}$ \\
\hline
\end{tabular}

Kegiatan pemberdayaan berbasis Masjid yang dilakukan oleh mahasiswa KKNPPM Tematik di desa Mulyoasri, Kecamatan Ampelgading, Kabupaten Malang ini didasarkan kepada fakta bahwa masyarakat desa setempat adalah masyarakat yang beragama Islam dengan aliran Aswaja yang umumnya merupakan masyarakatat yang berafiliasi dengan Nahlatul Ulama secara kultural yang secara konsistem menajalnkan amaliah Aswaja. Fakta ini adalah potensi yang harus dikembangkan melalui berbagai kegiatan pembedayaan masyarakat berbasis Masjid.

Menurut Latuconsina (2019), NU memiliki potensi masa yang besar di Indonesia, seharusnya menjadikan NU semakin berkembang luas dan diterima masyarakat di seluruh wilayah Indonesia (meng-NU-kan Indonesia) melalui sistem pengkaderan kuat yang terstruktur serta tersistematis agar mampu menghasilkan kader-kader yang militan dan faham akan khittah NU, sehingga NU semakin membumi dan tersebar luas di seluruh wilayah Indonesia. Hal ini sangat dimungkinkan karena NU dengan empat sikap dasar yaitu : Sikap Tawassuth, Tasamuh, Tawazun, serta Amar ma'ruf dan nahi munkar merupakan modal penting untuk lebih mudah diterima oleh masyarakat Indonesia yang multikultural.

Tawassuth berintikan kepada prinsip hidup yang menjunjung tinggi keharusan berlaku adil dan lurus di tengah-tengah kehidupan bersama, tidak ekstrim (baik ke kanan maupun ke kiri). NU dengan sikap dasar ini akan selalu menjadi kelompok panutan yang bersikap dan bertindak lurus dan selalu bersifat membangun serta menghindari segala bentuk pendekatan yang ekstrim. Tasamuh adalah sikap yang lemah lembut dan saling pemaaf serta merupakan akhlak terpuji dalam pergaulan, di mana terdapat rasa saling menghargai antara sesama manusia dalam batas-batas yang diajarkan oleh ajaran Islam. Tawazun adalah sikap seimbang atau adil dalam 
menghadapi suatu persoalan. dan Amar ma'ruf dan nahi munkar adalah perintah untuk mengajak atau menganjurkan hal-hal yang baik dan mencegah hal-hal yang buruk bagi masyarakat (Latuconsina 2019).

\section{Evaluasi Kegiatan Pemberdayaan Berbasis Masjid}

Program pemberadayaa berbasis Masjid yang laksanakan oleh kelompok 24 terlaksana dengan cukup baik, dimana mendapat respon positif dari orang tua dan anak-anak yang mengikuti progam unggulan maupun progam pendukung. Meskupun demikian efektifitas dan kesuksesan program ini akan dapat tergambarkan setelah kegiatan KKN-PPM Tematik berbasis Masjid ini berkahir dan butuh beberapa bulan setelahnya untuk dapat mengevaluasi keberhasilan berdasarkan indicator keberlanjutan program yang dijalankan oleh masyarakat secara mandiri. Terdapat kendala-kedala dalam upaya pemberdayaan masyarakat, salah satu kendalanya berasal dari kepribadian individu yang dapat berupa:

a. Kestabilan yang merupakan dorongan internal individu untuk menstabilkan dorongan dari luar,

b. Kebiasaan, yang biasanya dilakukan oleh masyarakat,

c. Hal yang utama yang terkait dengan hal-hal yang berhasil mendatangkan hasil yang memuaskan,

d. Seleksi ungatan dan persepsi adala sikap yang sudah terbtuk dalam menghadapi objek sikap yang dijumpai,

e. Ketergantungan terhadap orang lain yang menghambat proses "pemandirian" masyarakat,

f. Superego yang terlalu kuat membuat seseorang tidak mau menerima pembaharuan,

g. Rasa tidak percaya diri yang merupakan konsekuensi dari ketergantungan superego pada masa anak-anak yang berlebihan, dan

h. Rasa tidak aman dengan akan adanya perubahan yang dapat meningkatkan kecemasan dan ketakutan.

Dari hasil pelaksaanaan pemberdayaan masyarakat berbasis masjid yang dijalankan olek mahasiswa peserta KKN-PPM Tematik, maka dapat direkomendasikan beberaa hal yang harus dilanajkan agar kegiatan pemberdayaan seperti ini dapat semakin efektif dan dilaksaakan secara berkelanjutan, yaitu:

a. Melakukan Penyuluhan pemberdayaan masjid secara simultan dengan melibatkan tokoh agama maupun organisasi kemasyarakatan yang berbasis Islam seperti Nahdlatul Ulama untuk dapat mendorong peningkatan nilai-nilai Islam yang berhaluan Islam Ahusunnah Waljama'ah yang berpedoman kepada empat prinsip sebagai karket Ke-Aswajaan, yaitu: Tawassuth, Tawazzun, Tasamuh dan I'tidal. Sehingga dapat merespon segara perubahan dan dinamika sosial yang ada di tengah masyarakat,

b. Melakukan Monitoring dan evaluasi terkait segala bentuk kegiatan keagamaan yang berbasis Masjid, sebagai informasi dasar untuk merancang program yang lebih bermanfaat langsung dan menyentuh persoalan-persoalan kontemporer di tengah masyarakat,

c. Meningatkan intensitas komunikasi dan konsultasi publik dengan masyarakat setempat, untuk mendapatkan berbagai informasi persoalan sosial kemasyarakatan yang bisa didekati dengan program pemberdayaan berbasis Masjid. 


\section{KESIMPULAN}

Kegiatan Kuliah Kerja Nyata - Pendidikan Pemberdayaan Masyarakat Tematik (KKN-PPM Tematik) berbasis Masjid yang dilaksanakan oleh Kelompok 24 Mhasiswa Universitas Islam Malang dengan Tema "Peningkatan Ibadah dan Amaliah Sosial Berbasis Masjid" mendapatkan sambutan positif dari masyarakat khusunya pedukuhan Mulyoasri.

Dua program unggulan yang laksanakan adalah 1) Pelatihan sholat 5 waktu bagi anak-anak usia dini, yang didukung dengan program tambahan yaitu pengajaran membaca Al-Qur'an, dan 2) Jumat Sedekah berbasis Masjid dengan didukung beberapa program tambahan yang meliputi a) Penyuluhan Pemberdayaan dan Kemakmuran Masjid, Juma'at bersih Masjid sebagai bentuk pemberdayaan Masjid, dan b) Khotmil Qur'an ba'da subuh, Tahlilan, Asyrokalan, dan Diba'an sebagai bentuk partsipasi mahasiswa KKN-PPM dengan masyarakat desa sekaligus upaya mensinergikan antara program pemberdayaan dengan rutinitas amalan-amalan Islam Aswaja yang dijalankan oleh masyarakat desa selama ini.

Harapannya semoga kegiatan pemberdayaan yang dilakukan ini dapat terus berlanjut yang dilakukan oleh masyarakat desa secara mandiri, sebagai manifestasi peningkatan ibadah dan amaliah sosial untuk meningkatkan hablum minallah dan Hablum minannas dalam upaya mencapai insan khamil.

\section{UCAPAN TERIMA KASIH}

Ucapan terima kasih disamapaikan kepada Kepala Desa Mulyoasri beserta Perangkat Desa dan kepala Dusun Mulyoasri yang telah menerima dan membantu mahasiswa peserta KKN-PPM Tematik selama 1 bulan penuh daam menjalankan program kerja. Ucapan terima kasih juga disampaikan kepada Panitia KKN-PPM Tematik dan Ketua LPPM Universitas Islam Malang yang telah memberikan kesempatan dan memudahkan terlaksananya kegiatan KKN-PPM Tematik.

\section{DAFTAR RUJUKAN}

Aristanto, E., Hidayatullah, S., Rachmawati, I. K., Waris, A., \& Khalikussabir, K. (2020). Peningkatan Fasilitas Bagi Tahfizh Anak Usia Dini "Kuttab Rumah Quran" Menuju Persaingan Pendidikan Anak Pra Sekolah. Jurnal Inovasi Hasil Pengabdian Masyarakat (JIPEMAS), 3(1), 78-86. https://doi.org/10.33474/jipemas.v3i1.4763

Astuti, R., \& Aziz, T. (2019). Integrasi Pengembangan Kreativitas Anak Usia Dini di TK Kanisius Sorowajan Yogyakarta. Jurnal Obsesi : Jurnal Pendidikan Anak Usia Dini, 3(2), 294-302. https://doi.org/10.31004/obsesi.v3i2.99

Baiti, R., \& Razzaq, A. (2017). Esensi Wahyu Dan Ilmu Pengetahuan. Wardah, 18(2), 163180. https://doi.org/10.19109/wardah.v18i2.1776

Hamrin, N. K. B. (2018). Ikhlas Dalam Beramal Menurut Mufassir. Universitas Islam Negeri Sunan Ampel.

Hermawan, R. (2018). Pengajaran Sholat Pada Anak Usia Dini Perspektif Hadis Nabi Muhammad SAW. INSANIA : Jurnal Pemikiran Alternatif Kependidikan, 23(2), 282291. https://doi.org/10.24090/insania.v23i2.2301

Latuconsina, H. (2019a). Kebangkitan dan Pergerakan NU. Times Indonesia. https://www.timesindonesia.co.id/read/news/227162/kebangkitan-danpergerakan-nu

Latuconsina, H. (2019b). Membentengi Perguruan Tinggi dari Radikalisme. Kompas. https://kompas.id/baca/opini/2019/06/22/membentengi-perguruan-tinggi-dariradikalisme/

Martino, Y. A., Sulistiowati, E., \& Purnomo, Y. (2018). Model Pemberdayaan Santri Ponpes Al-Hidayah Batu Alang Sebagai Kader Kesehatan Berbasis Terapi Herbal. Jurnal 
Inovasi Hasil Pengabdian Masyarakat (JIPEMAS), 1(2), 86-93. https://doi.org/10.33474/jipemas.v1i2.1514

Morrisan. (2012). Metode Penelitian Survey. Kencana.

Nizar, M. (2011). Metode Penelitian.

Rahman, A. (2016). Pengaruh Negatif Era Teknologi Informasi Dan Komunikasi Pada Remaja (Perspektif Pendidikan Islam). AL-ISHLAH: Jurnal Pendidikan Islam, 14(1), 18-35. https://doi.org/10.35905/alishlah.v14i1.384

Rasikh, A. (2019). PEMBELAJARAN AL- QUR'AN HADITS DI MADRASAH IBTIDAIYAH : Studi Multisitus pada MIN Model Sesela dan Madrasah Ibtidaiyah At Tahzib. Jurnal Penelitian Keislaman, 15(1), 14-28.

Rusdi, A., Wicaksono, K. A., Ardiyantara, N., Saputro, T. A., Peduk, A., \& Ramadhani, K. (2018). Sedekah Sebagai Prediktor Kebahagiaan. Jurnal Psikologi Islam2, 5(1), 5968. https://doi.org/10.1007/978-94-007-0753-5_1544

Shihab, M. Q. (1996). Wawasan al-Quran: Tafsir maudhu'i atas pelbagai persoalan umat (Cet. 1 edi). Mizan.

Siregar, L. Y. S. (2016). Pendidikan Anak Dalam Islam. Bunayya: Jurnal Pendidikan Anak, 1(2), 16-32. https://jurnal.ar-raniry.ac.id/index.php/bunayya/article/view/2033

Ulfa, R. A., \& Arifi, A. (2017). Aktualisasi Pendidikan Al- Habit-Forming pada Anak Usia Dini di TK Al-Kautsar Durisawo Ponorogo. Al-Athfal: Jurnal Pendidikan Anak, 3(1), 65-81. http://ejournal.uin-suka.ac.id/tarbiyah/index.php/alathfal/article/view/1406

Yurwanto, Y. (2014). Memaknai Pesan Spiritual Ajaran Agama Dalam Membangun Karakter Kesalehan Sosial. Jurnal Sosioteknologi, 13(1), 41-46. https://doi.org/10.5614/sostek.itbj.2014.13.1.5 